\title{
Planning for Blended Learning for the Post-Pandemic Era
}

\author{
Sang E Park* \\ Associate Dean for Dental Education, Harvard School of Dental Medicine, USA \\ *Corresponding author: Sang E Park, Associate Dean for Dental Education, Harvard School of Dental Medicine, USA \\ To Cite This Article: Sang E Park. Planning for Blended Learning for the Post-Pandemic Era. Am J Biomed Sci \& Res. 2021 - 13(3). AJBSR. \\ MS.ID.001868. DOI: 10.34297/AJBSR.2021.13.001868.
}

Received: 㭗 June 23, 2021; Published: 眥 June 25, 2021

\section{Opinion}

A proliferation of online education has emerged in recent years, which was further propelled by the need to meet public safety measures caused by the COVID-19 pandemic. As we speculate the educational needs and approaches in the post-pandemic era, it is worthwhile to consider continuous development of blended learning, which is a combination of traditional face-to-face and online instructional method. Blended learning is described as a pedagogically planned integration of online and face-to face class activities using purposeful technologies with defined institutional pedagogical goals for the improvement of student learning [13]. An overarching goal of a blended education is to achieve an active and collaborative student-centered learning environment using online learning as a critical long-term strategy [2-4]. In this learning format, teachers can spend more time interacting with students instead of lecturing during the face-to-face class time, utilizing online delivery of contents with use of technology to reinforce learning

As we continue to explore improved methods to convey advanced concepts such as basic and medical science knowledge, hand skills and patient care, and advanced topics in biomaterials, the traditional face-to-face didactic teaching alone may not be most effective. It would be important to consider how students learn best, and how we can improve their learning through collaborative and interactive process as we stride to educate the reflective practitioner to achieve higher levels of learning [5-7]. Resource allocation to blended course design and delivery suggests its priority for dental education. Online learning may require a physical setup different from the typical one to many, or faculty to student, presentation setup; an online video component will also need to be introduced and made available to students. Faculty and students who have no prior experience with this model may find it difficult to adjust their expectations regarding the way class time is used. Blended learning takes it one step further by augmenting the traditional classroom setting and providing opportunities to engage in collaborative activities based on team-based projects and games in the classroom at various capacities $[1,7,8]$. The interactive online learning platform is capable of providing the students with of an educational method to improve students' learning experience and teaching methods. We can further explore introducing an online model for an expanded use of technology leading to new innovations that incorporate a digital teaching tool into educational pedagogy.

\section{References}

1. Park SE, Howell TH (2015) Implementation of a flipped classroom educational model in a pre-doctoral curriculum. Journal of Dental Education 79(5): 563-570.

2. Picciano AG (2011) Introduction to the special issue on transitioning to blended learning. Journal of Synchronous Leaning Networks 15(1): 3-7.

3. Garrison DR, Vaughan ND (2008) Blended learning in higher education. Framework, principles and guidelines. San Francisco.

4. Chutinan S, Riedy C, Park SE (2018) Student performance in a flipped classroom dental anatomy course. European Journal of Dental Education 22(3): 343-349.

5. Illeris K (2003) Toward a contemporary and comprehensive theory of learning. International Journal of Lifelong Education 22(4): 396-406.

6. McGee, Reis (2012) Blended course design: A synthesis of best practices. Journal of Asynchronous Learning Networks 16(4): 7-22.

7. Park SE, Yener E, Fazio S (2018) Use of team-based learning pedagogy for predoctoral teaching and learning. European Journal of Dent Education 23(1): 32-36.

8. Kennedy E, Park SE (2018) Designing Predoctoral Dental Education Pedagogy Utilization. West East Journal of Social Sciences 7(3): 1-9. 